\title{
Steering a Middle Course
}


The ISEAS - Yusof Ishak Institute (formerly Institute of Southeast Asian Studies) is an autonomous organization established in 1968. It is a regional centre dedicated to the study of socio-political, security, and economic trends and developments in Southeast Asia and its wider geostrategic and economic environment. The Institute's research programmes are grouped under Regional Economic Studies (RES), Regional Strategic and Political Studies (RSPS), and Regional Social and Cultural Studies (RSCS). The Institute is also home to the ASEAN Studies Centre (ASC), the Singapore APEC Study Centre, and the Temasek History Research Centre (THRC)

ISEAS Publishing, an established academic press, has issued more than two thousand books and journals. It is the largest scholarly publisher of research about Southeast Asia from within the region. ISEAS Publishing works with many other academic and trade publishers and distributors to disseminate important research and analyses from and about Southeast Asia to the rest of the world. 


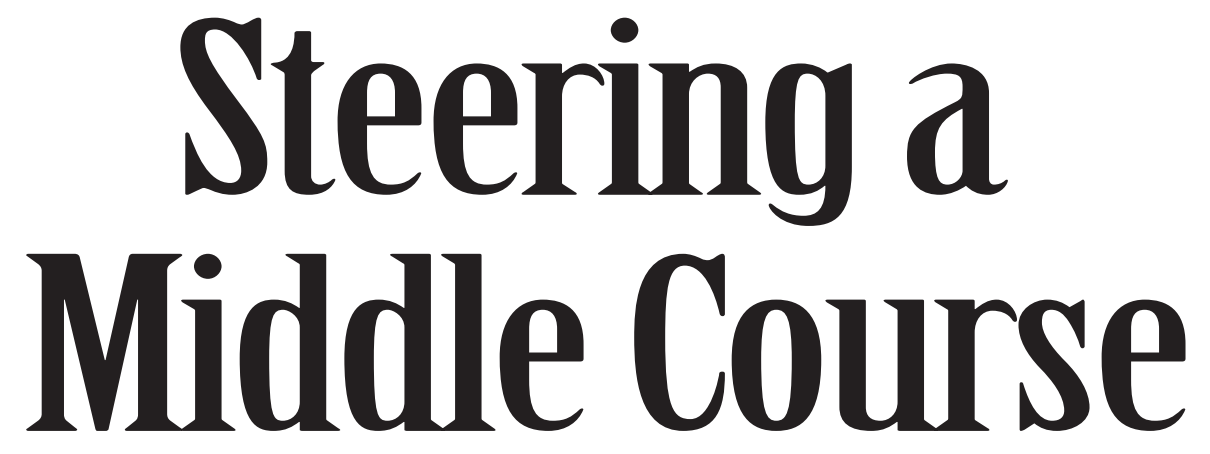

From Activist to Secretary General of Golkar

SARWONO KUSUMAATMADJA 
First published in Singapore in 2020 by

ISEAS Publishing

30 Heng Mui Keng Terrace

Singapore 119614

Email: publish@iseas.edu.sg

Website: bookshop.iseas.edu.sg

Originally published in Indonesian as

MEMOAR SARWONO KUSUMAATMADJA

"Menapak Koridor Tengah"

(C) 2018, Sarwono Kusumaatmadja

Licensed through PT Kompas Media Nusantara

All rights reserved.

Translated by Johannes Nugroho.

(C) 2020 ISEAS - Yusof Ishak Institute, Singapore

All rights reserved. No part of this publication may be reproduced, stored in a retrieval system, or transmitted in any form or by any means, electronic, mechanical, photocopying, recording or otherwise, without the prior permission of the ISEAS - Yusof Ishak Institute.

The responsibility for facts and opinions in this publication rests exclusively with the author and his interpretations do not necessarily reflect the views or the policy of the publisher or its supporters.

\section{ISEAS Library Cataloguing-in-Publication Data}

Name(s): Kusumaatmadja, Sarwono, author. I Nugroho, Johannes, translator.

Title: Steering a middle course / by Sarwono Kusumaatmadja.

Description: Singapore : ISEAS - Yusof Ishak Institute, 2020. I Includes bibliographical references and index. I English translation of Menapak Koridor Tengah.

Identifiers: ISBN 9789814881654 (soft cover) | ISBN 9789814881661 (PDF) | 9789814881746 (epub)

Subjects: LCSH: Kusumaatmadja, Sarwono-Biography. I Cabinet officersIndonesia-Biography. I Politicians-Indonesia-Biography. I Indonesia-Politics and government-1966-1998. I Indonesia-Politics and government-1998-

Classification: LCC DS644.62 K97A3

Typeset by International Typesetters Pte Ltd

Printed in Singapore by Markono Print Media Pte Ltd 
Dedicated to the current and future generations.

May you succeed in your endeavours so that our nation can stand tall. 
